\title{
The Significance Of Work Ethics İn Human Resource Management For Upgrading The Performance Of Employees: An Applied Study
}

\author{
Dr. Belal A. Mathani \\ Ajloune National University
}

doi: 10.19044/esj.2016.v12n4p231 URL:http://dx.doi.org/10.19044/esj.2016.v12n4p231

\begin{abstract}
This study was aimed at learning about the reality of work ethics practices in human resource management. This work was performed in conjunction with organizations that are affiliated with public services, such as Greater Irbid Municipality. It measured their effectiveness in raising the standard of performance. Additionally, the aim of the study is to identify the most important fields of application of work ethics in human resource management (attracting human resources, training and development, remuneration and rewards, and evaluating employees). The study begins with addressing the problem through the aforementioned main premise. However, there was no statistically significant impact at $a=0.05$ level of significance for work ethics practices in human resource management to improve the performance of the workers of Greater Irbid Municipality. Following up the descriptive analytical method, the study has shown that there is a statistically significant relationship between the dimensions of work ethics practices in human resource management in improving the performance of Greater Irbid Municipality. The sample of the study was made up of a population of 350 employees of Greater Irbid Municipality, who were selected by random method. The study analyzes the aforementioned items under two hypothetical theories using the well-known six statistical methods. The methods showed that the samples fell in a range greater than $0.05 \geq \alpha$ which were proven to be within a normal distribution. Additionally, the linear correlation test showed that the inflation coefficient of variation (VIF) is ranged between 2.22 and 4.30, while the Tolerance value for all independent variables greater than 0.05 ranged between 0.23 and 0.45 . Therefore, it can be said that there is no high correlation problem between independent variables. This enhances the possibility of finding out which of the independent variables have a statistically significant impact on development variables, as well as to know the percentage of that impact factor. Furthermore, the methods showed the correlation between dependent
\end{abstract}


and independent variable, giving a value greater than 0.77 and an R-square value of 0.58 . This is statistically significant, which reveals the effectiveness of work ethics of human resource management in influencing the performance level.

Keywords: Human resources management, performance of employees, work ethics, Greater Irbid Municipality

\section{Introduction}

Human elements are considered the most important resources in an organization. This essential effective element plays a major role in this activity. There are several definitions of human resource management. Abbas (2006) indicated that human resource management means that being interested in the affairs is the most important element of the production process of human elements. Thus, this is considered as the essential engine for productivity and profitability through guidance and leadership for various resources. In a study, Almusawi (2004) explored "the plan, organization, control, attraction, development, rewards, integration, and maintenance of human resources for the purpose of achieving the organization's aims.”

Ethics generally indicates the standard of moralities in the society on which individuals learn to distinguish between what is true and what is false. Almunjed dictionary defines the word "moral" as gallantry, habit, nature, and trait. AL fayroz Abadi (2003) indicated that "the ethics" are gathering moral. Thus, moral means religion, trait, gallantry, nature, which is intrinsic, and it is the same in description and meaning. Ethics considers spruced up characters of individuals and society alike. Additionally, Al-Doori (2010) has defined ethics idiomatically: it means the personal individuality of beliefs that relates to right and wrong actions. Ethics is a mirror through which we recognize the actions of individuals. Also, it can be said that ethics represents a set of rules of behaviors to which the man in the community adheres and adjusts. The human resource department of an organization is the intellectual capital and basis for the creation of competitive advantage. And because the capabilities of human resources are renewable, the enterprise management attaches interest and bears their social and ethical responsibilities to the fullest.

Researchers have tried hard to identify elements of performance in order to support and develop the effective job performance of employees. Dorah (2003) mentioned that performance elements "are efficient employees, requirements work, and environment regulations.” Consequently, determining the required level of performance requires a knowledge of the factors that determine this level. Zidan (1984) has mentioned that "the individual's performance does not only depend on their abilities, but also 
depends on their motivation. Also, the motivation of individuals does not depend on physical working conditions, but depends on social conditions of the interaction between the saturated needs of individuals that do not impel the behavior."

The subject of work ethics has gained large interest from administrators who are interested in organizational behaviors. Besides, this subject has become an essential modern topic for successive organization. Furthermore, the subject resonates highly, especially in the light of recent trends towards globalization and the result thereof in increased knowledge and cultural expansion and mixing of culture and civilization. The subject does not end at this stage, but rather it takes on another dimension in the practical life of organizations, where the individual's moral behavior is influenced by several positive or negative influences, internal and external. Consequently, the impacts of these influences overwhelm and affect the behavior of individuals within the organization, and thus, provide the satisfaction or dissatisfaction of employees within the organization. Thus, employees' achievements are reflected by the performance within their work. Therefore, business ethics is considered a key part of the prosperity and healthy growth of industry enterprise. Understanding the value of ethics for work led to the emergence of several aspects, including the spread of the concept of social responsibility and ethics. This motivates departments and employees alike to act in accordance with ethical standards. Based on the foregoing discussion, the scope of this study is to address work ethics from several angles as an important and vital subject in modern successful management organizations. This study also relates to the scale effectiveness of human resource management work ethics in performance upgrades in Greater Irbid Municipality. In this study, we will look at some of the activities that are carried out by the human resource management to learn how an organization can embrace the embodiment of ethical behavior. This is because it will reflect positively on attracting human resources as well as training and development. We will also study the wages and bonuses of employees in the organization as well as the evaluation of employees.

\section{The Scope of the Study and its Questions}

Work ethics is considered an important and essential parameter which measures the success of both management and employees in an enterprise environment. Human resource management is considered a major administration department of the most influential organizations responsible for its success or failure. The problem of the study is as follows: How much influence over the work ethics of human resource management does upgrading performance within Great Irbid Municipality have? 
Hence, this study tries to reach desired results through answering the following fundamental questions?

1- What is the concept of work ethics, and what is its aims?

2- What is the commitment of human resource management in Greater Irbid Municipality in applying business ethics?

3- What is the impact of ethical practices on human resources activities in Greater Irbid Municipality in leveraging employees’ performance within it?

\section{Significance of the Study}

This highlights the importance of the study, which is the importance of business ethics and their impact on the general behavior of employees within their organization. So this study tries to reach the results and recommendations that can be tapped and used by administrative leaderships to contribute to the best kinds of ethical behavior for employees. In addition, this study aims to propagate the knowledge of Jordanian Institutions on the impact of business ethics on the interests of the institution and the social environment of the society. This study changes the look of all Jordanian institutions, particularly those who view business ethics from an administrative angle with respect to legal norms, and regardless of the method or manner they can perform these actions.

\section{The Goals of the Study}

The aim of this study is to recognize the reality of work ethics practices in activities like human resource management for working organizations in public services sector. However, Greater Irbid Municipality represents one of these institutions and we measure their effectiveness in raising the standard of performance. In the light of this fundamental purpose, the range of subsidiary purpose falls within the following:

1- Find out about the reality of the commitment of human resource management in Greater Irbid Municipality.

2- Find out about the most important fields of application of ethics work in human resources management's (attracting human resources, training and development, remuneration and rewards of employees, and evaluating employees) impact on the performance of employees in Greater Irbid Municipality.

3- Find out whether there is a link between human resource management's commitment to business ethics and the performance of employees in Greater Irbid Municipality.

4- Verify the extent of the senior management recognition or influence and the work ethics' role in human resource management. 


\section{Boundary of the Study}

The generality of this study depends on several factors, as follows:

Substantive Limits: The study is limited to the impact of business ethics on human resources at the level of performance in Greater Irbid Municipality.

Humanity Limits: The study is limited to a random sample of employees in Greater Irbid Municipality.

Place Limits: This study is conducted in Jordan - Irbid

Time Limits: This study is implemented between Jan. 1, 2015 and Aug. 1, 2015

\section{Variables of the Study}

Independent Variable

Attracting human resources

Training and development

Wages and awards for employees

Evaluating employees

\section{Dependent Variable}

Official performance of employees

Additional performance of employees

\section{Hypotheses of the Study}

The study addresses the problem through the following hypotheses:

The main hypothesis of this research: is due to the fact that there is no statistically significant impact factor at $a=0.05$ level of significance of work ethics practices of human resource management to improve the performance in Greater Irbid Municipality.

Further derived subsidiary hypotheses from the main hypothesis are summarized as follows:

- There is no statistically significant positive impact at $\mathrm{a} \leq 0.05$ level of significance of dimensions of practice of human resource management work ethics to improve official performance for employees.

- There is no statistically significant positive impact at $a \leq 0.05$ level of significance of dimension of practice of human resource management work ethics to improve additional performance for employees.

\section{Background and Basic Concepts}

Human resource management is widely known as a group of related administrative activities targeted at obtaining the organization's needs from human resources. It develops, stimulates, and discusses what enables the achievement of organizational aims at the highest levels of efficiency and 
effectiveness. The human resources management of the modern form is not a product of time, but a result of the number of developments that dates back to the beginning of the industrial revolution. These developments contributed to show the existing need for specialized human resource management to promote employees' affairs in the organization. There are several reasons responsible for the growing interest in human resource management as a specialized function and branch of management. These result in expansion and industrial development in modern era. Also, it results in the need for specialized management to promote and solve the problems of human resources in the company, as well as the significant expansion in education and cultural opportunities for employees. This leads to increased awareness as a result of rising cultural and educational level, which requires the existence of specialists in human resource management and modern method of dealing with modern varieties.

\section{The Concept of Work Ethics}

The concept of work ethics is simply based on a set of rules and principles that must be observed and adhere to and acted upon to be successful in dealing with people and their career. The ethical standards in the field of business are associated with the ethical standards of the individuals. Abu Baker (2010) broadly defined business ethics as "a set of principles and rules and regulations that are formed from specific sources and become the reference case from standards." Consequently, it determines the method of thinking and behavior of individuals of an organization to distinguish between what is acceptable and what is unacceptable, what is true or false, and what is legal and what is illegal. This includes the consequent career managerial behavior, leadership and institutional uncontrolled moral and value judgment from the points of view of the institution and society. Thus, it can be said that work ethics is the product of all morals because it is formed from individual value and behavior that dictate response to situations, which do not violate prevailing values and customs in their community and workplace.

\section{Ethics in Business}

The importance of business ethics, both to organizations and individuals who belong to these organizations and interested parties, is to strengthen compliance with the principles and values of the right work. AlGalibi, Taher et al. (2010) have stated the importance of ethics in the field of work to get the following benefits:

1- Cannot accept the traditional perspective of work and who sees a conflict between achieving the interests of the organization in financial gain and commitment to ethical standards. 
2- Could cost business organizations a lot as a result of ignorance of the commitment to ethical standards.

3- To enhance the reputation of the organization at the local, regional, and international level of the environment, and this has a positive effect on the organization.

4- The recent trends ignore ethics in business leading to a displacement of some narrow self-interest.

5- The international certificates and privileges (such as ISO) is associated with many of the organization's ethical standards.

\section{Sources of Business Ethics}

Yaghi (2001) indicated "that business ethics can be based on two pillars/main components." The first is social and moral values, customs, and traditional systems that prevail in the community. The second is the value system of self-related personality and beliefs that is based on their previous experience. AL-Sakarneh (2009) stated that there are identifiable sources of business ethics that embody an ethically good behavior or bad as follows:

1- $\quad$ Family and environmental education

2- $\quad$ Community cultural values and habits

3- $\quad$ The efficiency of resource groups

4- $\quad$ The school and educational system in communities

5- $\quad$ Country advertisement, media, and opinion institutions

6- $\quad$ The first community work

7- $\quad$ Old authority and personal values that is inherent among workers

8- $\quad$ Laws and government regulations and legislation

9- Laws and moral cognitive behavior of the industry and the professions

10- Accumulated experience and good human conscience

11- $\quad$ Pressure groups in civil society

\section{Business Ethics}

The institution can assume social responsibilities and ethical behavior towards human resources through several ways. These are summarized by Jeldeh (2010) who incorporated social responsibility and ethical behavior towards human resource in work organization. They are:

1- Mobilize and attract human resources

2- Interview, selection, and recruitment

3- Training and development

4- Wages and bonuses of employees

5- Evaluating the performance of employees

6- Programs that improve the quality of life of workers

7- Working women 
Abu Baker (2010) also stated that moral and values practices in human resources are as follows:

1- Approach thinking in human resource management

2- Ethics and values work in stowage and attract human resources

3- Ethics and work values in the interview process and testing of applicants for jobs

4- Ethics and work values in the selection and appointment process

5- Ethics and work values in fields of training and human resource developments

6- Ethical works and values of work in the design and implementation of wages, salaries bonuses, and incentive structures

7- Ethics and values of work in the field of performance evaluation

\section{Performance of Employees}

There are multiple definitions of performance by researchers. Dorah (2003) defined it as: “...that achieves some terms and conditions which reflect the result or group of certain result for the behavior of a specific person or persons." Additionally, Aladela (1995) indicated "that the performance of an individual for his work is preceded by the process of trade-of and is based on the values that are expected in return." This is obtained from the performance of this work. Thus, the degree of this anticipation differs from one person to another and from one organization to another.

\section{Elements of Performance}

The main purpose of this study is to help officials to find out weaknesses and strengths in the activity of employees. This is done so as to address the weaknesses and strengths and to enhance it. We wish to emphasize that the performance of individuals is concordant with moral values. In addition, the manifestation of behavior and performance of an individual is dependent on his career leader. It is linked mainly with values.

\section{Previous Studies}

To form a more accurate picture of the subject of study, the researcher tried to get previous studies on the subject of work ethics in human resources and supplies the most relevant studies as follow:

\section{Atyani and Abu Salma Study (2014)}

This study was aimed at identifying the impact of ethical parties on the management of human resources and the satisfaction of the employees in cellular communications in Jordan companies. To achieve this purpose, the 
researchers developed a private questionnaire which was distributed to a sample of workers in the cellular communication in Jordan companies. Using appropriate methods of collecting and analyzing data to test hypotheses, the study concluded that the presence of impact was statistically significant for ethical practices. This applied to all fields influenced by the human resource department of satisfaction employees in Jordan communications companies. Furthermore, the practice of ethical aspects in human resources departments is based on principles of justice, equality, transparency, and integrity. It has a dramatic impact on morals, which is reflected on the state of job satisfaction. The researcher acted by submitting a set of recommendations and proposals, including the need to adhere to application of business ethics in all activities and functions of the organization. This is because it has a positive reflection on the employees of those companies. Also, their study effectuates in-depth study about the lack of commitment to business ethics in the Arab World and its impact on lower production and productivity levels, and increasing unemployment and poverty.

\section{Mayer et al. (2011)}

The study was aimed at recognizing the effect of leadership behavior on the behavior of employees. It was applied on the leaders and employees of American government companies and organization. The study discovered that there is an inverse relationship between climate moral and level of the misconduct and ethics of the employees, and that there was a significant relationship between the ethics of leadership and the level of misconduct of employees. Thus, this is in addition to the evidence of the moral climate on the conduct of employees' roles.

\section{Almqss, Mohammad et al. (2011)}

The study was aimed at identifying the degree of availability of code of public function ethics in performance functionality at the managers and teachers Education Central Badia. The results showed a high degree of availability of the ethics function in functionality performance to the mangers and teachers Education Central Badia.

\section{The Study of Hussein and Jamil (2009)}

It researched the relationship between the dimensions of social responsibility towards employees and work ethics. The study found that the concept of social responsibility is considered one of the concepts that gained attention. Most contemporary organizations were expressed in the past on profit maximization during the period of the sixties. At present, the concept has become coupled with the social aspect of the organization. It explained that there are several dimensions of social responsibility towards the 
employees. As the organization must pay attention to it, the organization introduced it to achieve the objectives of employees and increase their loyalty and interest in the organization.

\section{The Study of John Simmons (2008)}

This focused on the social responsibility of organizations and evaluated the ethical aspects in work ethics of human resources departments. The study has calculated that to be considered at the global parlance, justice and quality are the most critical factors in judging the maturity of the social responsibility of an organization from the point view of its employees.

\section{The Study of Al hanith (2003)}

This study was aimed at identifying the reality of the prevailing values among workers in medical services and the relationship between them and the efficiency of the performance of workers. Also, it studies the relationship between them and the personal variables to them. The researcher used the descriptive approach based on a questionnaire to measure the prevailing organizational values and the level of efficient performance among the workers. The study found that the number of results, including the applicable organizational values of researchers, were high. The study classified efficiency performance among workers in general as high. It recommended the need to conduct further studies and research on the subject of organizational values. It also unveiled a link to other variables such as administrative work and religious faith development by upholding Islamic values which guide the behavior of employees.

\section{Results and Discussions}

This part includes an exposition and analysis of the data that was accumulated by the researcher through the questionnaire that was distributed to respondents in Great Irbid Municipality. This will be followed by a description of the demographic and functional characteristics of the respondents. Then, an analysis and discussion of the answer to individual paragraphs of the questionnaire relating to each of the dimensions of the independent variables is given. The answers to the paragraphs related to dependent variables identify the level of work ethics of human resources management and the level of performance of employees in organization. This part will be as a test of validity of the hypotheses mentioned in this study for the purpose of identifying the impact of effectiveness on work ethics in human resource management in raising the level of performance employees. 


\section{Study Samples}

The sample of the study consisted of 350 employees of Greater Irbid Municipality. These ones were selected from the study population by random method. Where the researcher distributed 400 questionnaires to the staff of Greater Irbid Municipality, he retrieved 362 questionnaires. After reviewing the questionnaire, it showed that there were 12 invalid questionnaires for statistical analysis because of incomplete data or lack of seriousness. Thus, the number of sample individuals was 350, translating in percentage to $10 \%$, from the study population of 3500. Table 1 shows the distribution of individual's samples.

Table 1. Distribution of the individual samples according to personal variables $(n=350)$

\begin{tabular}{|c|c|c|c|}
\hline Variable & Level & Frequency & Percentage \\
\hline \multirow{3}{*}{ Gender } & Male & 221 & 63.1 \\
\hline & Female & 129 & 36.9 \\
\hline & Sum & 350 & 100.0 \\
\hline \multirow{5}{*}{ Social Situation } & Unmarried & 105 & 30.0 \\
\hline & Married & 245 & 70.0 \\
\hline & Widower & - & - \\
\hline & Divorce & - & - \\
\hline & Sum & 350 & 100.0 \\
\hline \multirow{6}{*}{ Age } & Less than 30 year & 62 & 17.7 \\
\hline & 30- less than 40 & 169 & 48.3 \\
\hline & 40- less than 50 & 108 & 30.9 \\
\hline & 50 - less than 60 & 11 & 3.1 \\
\hline & 60 and over & - & - \\
\hline & Sum & 350 & 100.0 \\
\hline \multirow{6}{*}{ Qualification } & Less than Tawjihi & 22 & 6.3 \\
\hline & Tawjihi & 42 & 12.0 \\
\hline & Diploma & 160 & 45.7 \\
\hline & Bachelor & 126 & 36.0 \\
\hline & Postgraduate studies & - & - \\
\hline & Sum & 350 & 100.0 \\
\hline \multirow{4}{*}{ Current Job } & Administrative & 296 & 84.6 \\
\hline & Technician & 32 & 9.1 \\
\hline & Worker & 22 & 6.3 \\
\hline & Sum & 350 & 100.0 \\
\hline \multirow{7}{*}{ Experience in current job } & Less than 5 years & 10 & 2.9 \\
\hline & 5 - less than 10 years & 156 & 44.6 \\
\hline & 10 - less than 11 years & 96 & 27.4 \\
\hline & 11 - less than 15 years & 55 & 15.7 \\
\hline & 15 -less than 20 years & 33 & 9.4 \\
\hline & 20years and over & - & - \\
\hline & Sum & 350 & 100.0 \\
\hline \multirow{5}{*}{$\begin{array}{l}\text { Degree from 100, which } \\
\text { gives the level of human } \\
\text { resources management } \\
\text { ethics in institution }\end{array}$} & Less than $50 \%$ & 66 & 18.9 \\
\hline & $50-64 \%$ & 98 & 28.0 \\
\hline & $65-79 \%$ & 138 & 39.4 \\
\hline & $80 \%$ and over & 48 & 13.7 \\
\hline & Sum & 350 & 100.0 \\
\hline
\end{tabular}


Table 1 shows the following:

1- The number of male in the study sample reached 221 (63.1\%), while the number of females reached 129 (36.9\%).

2- The highest percentage for distribution of the sample of individuals according to social situation variable reached $70.0 \%$ for married, while the lowest percentage reached $30.0 \%$ for unmarried.

3- The highest percentage for distribution of the sample individuals according to age variable reached $48.3 \%$ for age group 30 -less than 40 years, while the lowest degree reached $3.1 \%$ for age group 50-less than 60 years.

4- The highest percentage for distribution of the individuals of the sample according to qualification variable reached $45.7 \%$ for diploma qualification, while the lowest percentage reached $6.3 \%$ for less than Tawjihi qualification.

5- The highest percentage for distribution of individuals of the sample in accordance to current job variable reached $84.6 \%$ for administrative job, while the lowest percentage reached 3.6\% for work job.

6- The highest percentage for distribution of the individuals of the sample in accordance to experience in current job reached $44.6 \%$ for experience period variable 5-less than 10 years, while the lowest percentage reached $2.9 \%$ for period experience of less than 5 years.

7- The highest percentage for distribution of the individuals of the sample in accordance to the degree from 100 which gives the level of human resource management ethics in institution variable reached $39.4 \%$ for group $65-79 \%$, while the lowest percentage reached $13.7 \%$ for group $80 \%$ and over.

\section{Stability of Tools and Practices}

To ensure the stability of the performance, the study has been verified for application stability through the distribution of the study tool on a scoping sample consisting of 120 employees from outside the study sample twice a two-week lag. Extraction of the correlation coefficient (Pearson correlation) between the score on both occasions, as shown in table 2, showed the stability coefficients of the dimensions of the study and the tool as a whole. As can be seen from the table, the stability coefficients for the dimensions of the study ranged between $0.75-0.86$. All values are high and accepted for the purpose of the application also. 
Table 2. Reliability coefficient (Cronbach’s Alpha) and Pearson Correlation for study tool

\begin{tabular}{|c|c|c|c|}
\hline Domain & Dimension & Cronbach's Alpha & Pearson Correlation \\
\hline \multirow{4}{*}{$\begin{array}{c}\text { Effectiveness of work } \\
\text { ethics in human } \\
\text { resource management }\end{array}$} & $\begin{array}{c}\text { Polarizing human } \\
\text { resources }\end{array}$ & 0.77 & 0.86 \\
\cline { 2 - 4 } & $\begin{array}{c}\text { Rumination and } \\
\text { rewards for employees }\end{array}$ & 0.83 & 0.76 \\
\cline { 2 - 4 } & $\begin{array}{c}\text { Employees' evaluation } \\
\text { Effectiveness of work } \\
\text { ethics in human } \\
\text { resource management } \\
\text { as a whole }\end{array}$ & 0.75 & 0.87 \\
\cline { 2 - 4 } & $\begin{array}{c}\text { Training and } \\
\text { development }\end{array}$ & 0.82 & 0.83 \\
\hline \multirow{3}{*}{ Performance } & Official performance & 0.83 & 0.84 \\
\cline { 2 - 4 } & Additional performance & 0.76 & 0.85 \\
\cline { 2 - 4 } & Performance as a whole & 0.77 & 0.83 \\
\hline
\end{tabular}

\section{Scale Alternation}

The analysis of the data and test of the hypotheses of the study were based on the scale of Likert Quintet which is summarized in the following:

Answering paragraph, according to the following degree; level 1: agree in very low degree, level 2: express to agree in low degree, level 3: express to medium level, level 4: express to agree in strong level, level 5: agree in very strong degree. From the interpretation of arithmetic mean to estimates individuals of the study sample on each paragraph in the questionnaire paragraphs and on each of the fields, the statistical standard used is shown in table 3.

Table 3. Questionnaire Scale Test

\begin{tabular}{|c|c|c|c|c|c|}
\hline Level & 1 & 2 & 3 & 4 & 5 \\
\hline $\begin{array}{c}\text { Approval } \\
\text { level }\end{array}$ & $\begin{array}{c}\text { Agree in very } \\
\text { low degree }\end{array}$ & $\begin{array}{c}\text { Agree in low } \\
\text { degree }\end{array}$ & $\begin{array}{c}\text { Agree in } \\
\text { medium level }\end{array}$ & $\begin{array}{c}\text { Agree in } \\
\text { strong degree }\end{array}$ & $\begin{array}{c}\text { Agree in very } \\
\text { strong degree }\end{array}$ \\
\hline
\end{tabular}

With regard to the limits adopted by this study, when commenting on arithmetic mean of the variable in the study model and the degree of approval, the researcher has identified three levels (high, medium, low) based on the following equation:

Length of period = (the upper limit of the alternative - the minimum limit of the alternative) / the number of levels

$1.33=3 / 4=3 /(1-5)$ and thus the levels are as follows :

- Low agree degree from 1-2.33

- Medium agree degree from 2.34-3.67

- High agree degree from 3.68-5

\section{Method of Data Analysis}

To achieve the purpose of the study and ensure the validity of the hypothesis, the researcher used statistical methods in the data analysis of the 
data collected during the field study, and it is entered into the computer for social and economic science (SPSS). The researcher used descriptive statistics methods for the characteristics of respondents by using frequencies and percentage. The researcher also used a set of inferential statistics methods to test the hypotheses of the study especially. The researcher used the following statistical methods:

1- Cronbach's alpha equation and coefficients correlation in a way of Pearson:

To check the stability of the study tool consistently applied.

2- The normal distribution test for study data, by using one-sample Kolmogorov-smirnov test.

3- Test variance inflation factor (VIF) and variation allowable test (Tolerance) is used to make sure that there is no high correlation between the independent variables.

4- Frequencies and percentage: To get a distribution of individual sample according to personal variables.

5- Arithmetic means and standard deviations: To recognize the level of work ethics and level of performance of employees.

6- Multiple regression equation: To recognize the impact of independent variables of the dimensions of work ethics in human resources management on dependent variables of the performance of employees.

\section{Results of Related Studies}

The results are related to arithmetic mean for individual sample answers about the dimensions of work ethics practices in human resource management. It was extracted from arithmetic mean and standard deviation for individual sample answers about dimensions of work ethics practices in human resource management. Table 4 illustrates this.

Table 4. The arithmetic mean and standard deviation for individual sample answers about dimensions of work ethics practices in human resources management in a descending order

\begin{tabular}{|c|c|c|c|c|c|}
\hline Rank & Number & Field & $\begin{array}{c}\text { Arithmetic } \\
\text { Mean }\end{array}$ & $\begin{array}{c}\text { Standard } \\
\text { Deviation }\end{array}$ & $\begin{array}{c}\text { Evaluation } \\
\text { Degree }\end{array}$ \\
\hline 1 & 2 & $\begin{array}{c}\text { Training and } \\
\text { development }\end{array}$ & 2.97 & 0.97 & Medium \\
\hline 2 & 3 & $\begin{array}{c}\text { Wages and } \\
\text { bonuses }\end{array}$ & 2.79 & 0.91 & Medium \\
\hline 3 & 1 & $\begin{array}{c}\text { Polarize the } \\
\text { human resources }\end{array}$ & 2.55 & 1.06 & Medium \\
\hline $\begin{array}{c}\text { The field of the effectiveness of work ethics } \\
\text { in human resource management as a whole }\end{array}$ & 2.70 & 0.87 & Medium \\
\hline
\end{tabular}


It is shown in table 4 that the arithmetic mean for the individual sample answers about dimensions of work ethics practices in human resource management which ranged between 2.54 and 2.97. The first was "training and development" field with arithmetic mean of 2.97 and medium evaluation degree. The second was wages and bonuses of employees with arithmetic mean of 2.79 and medium evaluation degree. The third was polarize human resource with arithmetic mean of 2.55 and medium evaluation degree. Fourth was the field of evaluation of workers with arithmetic mean of 2.54 and medium evaluation degree and the arithmetic mean average of the practice. The work ethics of human resource was 2.70 with medium evaluationdegree. Arithmetic mean and standard deviation for individual sample answers on the paragraphs of every dimension of work ethics practices in human resource management has been extracted. Table 5 illustrate this.

Table 5. The arithmetic mean and standard deviation for individual sample about dimension paragraph that polarize the human resource in a descending order

\begin{tabular}{|c|c|c|c|c|c|}
\hline Rank & Number & Paragraph & $\begin{array}{c}\text { Arithmetic } \\
\text { Mean }\end{array}$ & $\begin{array}{c}\text { Standard } \\
\text { Deviation }\end{array}$ & $\begin{array}{c}\text { Evaluation } \\
\text { Degree }\end{array}$ \\
\hline 1 & 3 & $\begin{array}{c}\text { Give sufficient time to provide the } \\
\text { advertised jobs }\end{array}$ & 2.94 & 1.35 & Medium \\
\hline 2 & 2 & $\begin{array}{c}\text { Explicitly announce vacancy } \\
\text { Polarization process based on } \\
\text { objectives and delicate } \\
\text { determination of needs from } \\
\text { requirements }\end{array}$ & 2.91 & 1.46 & Medium \\
\hline 4 & 4 & $\begin{array}{c}\text { Commitment to honest completion } \\
\text { during the polarization process }\end{array}$ & 2.48 & 1.20 & Medium \\
\hline 5 & 5 & $\begin{array}{c}\text { Polarization procedures is fair, } \\
\text { clear, and conspicuous }\end{array}$ & 2.40 & 1.18 & Medium \\
\hline 5 & 8 & $\begin{array}{c}\text { Municipality accepting objections in } \\
\text { the event of violations in the process } \\
\text { of polarization }\end{array}$ & 2.40 & 1.23 & Medium \\
\hline 7 & 6 & $\begin{array}{c}\text { Procedure polarization is fair and } \\
\text { far from patronages and instruments }\end{array}$ & 2.29 & 1.24 & Low \\
\hline 8 & 1 & $\begin{array}{c}\text { Securing equal opportunities for } \\
\text { applicants for jobs in the } \\
\text { municipality }\end{array}$ & 2.24 & 1.04 & Low \\
\hline \multicolumn{7}{|r|}{ Dimension (polarize human resource) as a whole } & 2.55 & 1.06 & Medium \\
\hline
\end{tabular}

Table 5 shows that the arithmetic mean for individual sample answers about dimension paragraph on polarize human resource ranged between 2.24 and 2.94. Paragraph 3 came first (give sufficient time to provide the advertised lobs) with an arithmetic mean of 2.94 and medium-evaluation degree. While paragraph 1 came last (securing equal opportunities for applicants for job in municipality) with an arithmetic mean of 2.24 in lowevaluation degree, and the average of dimension of arithmetic mean as a whole was 2.55 , with medium-evaluation degree. 
Table 6. The arithmetic mean and standard deviation for individual sample answers about paragraph dimension, training, and development in a descending order

\begin{tabular}{|c|c|c|c|c|c|}
\hline Rank & Number & Paragraph & $\begin{array}{c}\text { Arithmetic } \\
\text { Mean }\end{array}$ & $\begin{array}{c}\text { Standard } \\
\text { Deviation }\end{array}$ & $\begin{array}{c}\text { Evaluation } \\
\text { degree }\end{array}$ \\
\hline 1 & 1 & $\begin{array}{c}\text { Consideration for training and } \\
\text { development as a right for workers to } \\
\text { enhance the efficiency of the } \\
\text { organization }\end{array}$ & 3.31 & 1.29 & Medium \\
\hline 2 & 4 & $\begin{array}{c}\text { Not to use the training program to } \\
\text { squander resources for embezzlement } \\
\text { and administrative corruption }\end{array}$ & 3.04 & 1.06 & Medium \\
\hline 3 & 2 & $\begin{array}{c}\text { There is a private budget for training } \\
\text { and development }\end{array}$ & 2.97 & 1.08 & Medium \\
\hline 4 & 5 & $\begin{array}{c}\text { Training programs that offers career } \\
\text { advancement }\end{array}$ & 2.83 & 1.29 & Medium \\
\hline 4 & 6 & $\begin{array}{c}\text { Training programs that offers the } \\
\text { conveyance of scientific } \\
\text { development in field knowledge }\end{array}$ & 2.83 & 1.28 & Medium \\
\hline 6 & 3 & $\begin{array}{c}\text { The training focuses on social and } \\
\text { ethical aspects with the } \\
\text { organization's culture }\end{array}$ & 2.82 & 1.05 & Medium \\
\hline \multicolumn{7}{|r|}{ Dimension of training and development as a whole } & 2.97 & 0.97 & Medium \\
\hline
\end{tabular}

Table 6 shows that the arithmetic mean for individual sample answers about dimension paragraph of training and development ranged between 2.82 and 3.31. Paragraph 1 came first (consideration for training and development as a right of workers to enhance the efficiency of the organization) with an arithmetic mean of 3.31 and medium-evaluation degree. While paragraph 3 came last (the training focuses on the social and ethical aspects with the organization's culture) with an arithmetic mean of 2.82 and mediumevaluation degree. The arithmetic mean for dimension as a whole reached 2.55 with medium-evaluation degree.

Table 7. The arithmetic mean and standard deviation for individual sample answers about paragraph dimension (wages and bonus) in a descending order

\begin{tabular}{|c|c|c|c|c|c|}
\hline Rank & Number & Paragraph & $\begin{array}{c}\text { Arithmetic } \\
\text { mean }\end{array}$ & $\begin{array}{c}\text { Standard } \\
\text { Deviation }\end{array}$ & $\begin{array}{c}\text { Evaluation } \\
\text { Degree }\end{array}$ \\
\hline 1 & 6 & $\begin{array}{c}\text { There is a package of indirect } \\
\text { compensation such as health } \\
\text { insurance and social security }\end{array}$ & 3.43 & 1.09 & Medium \\
\hline 2 & 1 & $\begin{array}{c}\text { Inequality and raffle in bonus } \\
\text { systems, includes the ability of } \\
\text { development and innovation }\end{array}$ & 3.15 & 1.65 & Medium \\
\hline 3 & 7 & $\begin{array}{c}\text { Equality between man and women } \\
\text { in payment of wages of the same } \\
\text { office if efficiency is equal }\end{array}$ & 3.05 & 1.51 & Medium \\
\hline 4 & 5 & $\begin{array}{c}\text { Wages granted increased the } \\
\text { attraction of work (creative) }\end{array}$ & 2.97 & 1.40 & Medium \\
\hline 5 & 4 & $\begin{array}{c}\text { Wages are characterized by their } \\
\text { ability to motivate employees }\end{array}$ & 2.46 & 1.42 & Medium \\
\hline 6 & 2 & $\begin{array}{c}\text { There is justice and equality in } \\
\text { wages in the per. Functional level }\end{array}$ & 2.34 & 1.23 & Medium \\
\hline 7 & 3 & The efficiency into account in & 2.13 & 1.01 & Medium \\
\hline
\end{tabular}




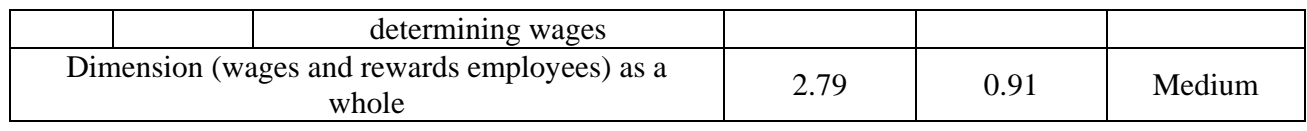

Table 7 shows that the arithmetical mean for individual sample answers about dimension paragraphs of wages and rewards ranged between 2.13 and 3.43. Paragraph 6 came first (there is a package of indirect compensation such as health insurance and social security) with an arithmetic mean of 3.34 and medium-evaluation degree. While paragraph 3 came last (the efficiency into account in determining the wages) with arithmetic mean of 2.13 and low-evaluation degree. The arithmetic mean of dimension as a whole reached 2.79 in medium-evaluation degree.

Table 8. The arithmetic mean and standard deviation for individual sample answers about paragraph dimensions of employees evaluating in a descending order

\begin{tabular}{|c|c|c|c|c|c|}
\hline Rank & Number & Paragraph & $\begin{array}{c}\text { Arithmetic } \\
\text { Mean }\end{array}$ & $\begin{array}{c}\text { Standard } \\
\text { Deviation }\end{array}$ & $\begin{array}{c}\text { Evaluation } \\
\text { Degree }\end{array}$ \\
\hline 1 & 3 & $\begin{array}{c}\text { The evaluation process } \\
\text { focuses on the latest } \\
\text { performance, regardless of the } \\
\text { performance during the year }\end{array}$ & 2.97 & 1.17 & Medium \\
\hline 2 & 1 & $\begin{array}{c}\text { The evaluation is carried out } \\
\text { by qualified staff in an } \\
\text { efficient manner }\end{array}$ & 2.53 & 1.40 & Medium \\
\hline 3 & 2 & $\begin{array}{c}\text { There is a clear interest in the } \\
\text { evaluation of the performance } \\
\text { of employees }\end{array}$ & 2.44 & 1.26 & Medium \\
\hline 3 & 6 & $\begin{array}{c}\text { Employees' evaluation } \\
\text { process is based on clear, } \\
\text { correct, and inclusive } \\
\text { standards }\end{array}$ & 2.44 & 1.24 & Medium \\
\hline 3 & 4 & $\begin{array}{c}\text { Evaluation process } \\
\text { characteristic of objectivity }\end{array}$ & 2.44 & 1.21 & Medium \\
\hline \multicolumn{2}{|c|}{6} & $\begin{array}{c}\text { Organization reward achievers } \\
\text { who offer new ideas }\end{array}$ & 2.41 & 1.04 & Medium \\
\hline \multicolumn{2}{|r|}{ Dimension (evaluation employees) as a whole } & 2.54 & 1.03 & Medium \\
\hline
\end{tabular}

Table 8 shows that the arithmetic mean for individual sample answers about dimension of evaluation employees ranged between 2.41 and 2.97. Paragraph 3 came first (the evaluation process focuses on the latest performance, regardless of the performance during the year) with arithmetic mean of 2.97 and medium-evaluation degree. While paragraph 4 came last (organization reward achievers who offer new ideas) with mediumevaluation degree. The arithmetic mean for the dimension as a whole reached 2.54 in medium-evaluation degree. The results were associated with the arithmetic mean for individual sample answers about dimensions of performance in employee's field. Arithmetic mean and standard deviation for individual sample answers about dimensions of performance in employees' field were extracted. Table 9 illustrates this. 
Table 9. The arithmetic mean and standard deviation for individual samples answers about dimensions of performance in employees' field in a descending order

\begin{tabular}{|c|c|c|c|c|c|}
\hline Rank & Number & Field & $\begin{array}{c}\text { Arithmetic } \\
\text { Mean }\end{array}$ & $\begin{array}{c}\text { Standard } \\
\text { Deviation }\end{array}$ & $\begin{array}{c}\text { Evaluation } \\
\text { Degree }\end{array}$ \\
\hline 1 & 1 & $\begin{array}{c}\text { Official } \\
\text { performance }\end{array}$ & 3.27 & 0.89 & Medium \\
\hline 2 & 2 & $\begin{array}{c}\text { Additional } \\
\text { performance }\end{array}$ & 3.23 & 0.86 & Medium \\
\hline \multicolumn{2}{|r|}{ Field of performance of employees' as a } \\
whole
\end{tabular}

Table 9 shows that the arithmetic mean for individual sample answers about dimensions of field performance of employees ranged between 3.23 and 3.27. The first, official performance, had an arithmetic mean of 3.27 and medium-evaluation degree. The second, additional performance, had an arithmetic mean of 3.23 and medium-evaluation degree. The arithmetic mean for field performance of employees was 3.26 with medium-evaluation degree. Arithmetic mean and standard deviation for individual sample answers about paragraph every dimension from level performance dimensions was extracted. Tables 10-11 illustrate this.

Table 10. The arithmetic mean and standard deviation for individual sample answers about paragraph dimension of official performance in a descending order

\begin{tabular}{|c|c|c|c|c|c|}
\hline Rank & Number & Paragraph & $\begin{array}{c}\text { Arithmetic } \\
\text { Mean }\end{array}$ & $\begin{array}{c}\text { Standard } \\
\text { Deviation }\end{array}$ & $\begin{array}{c}\text { Evaluation } \\
\text { Degree }\end{array}$ \\
\hline 1 & 2 & $\begin{array}{c}\text { I'm accomplishing my } \\
\text { responsibility and duties } \\
\text { accurately }\end{array}$ & 3.55 & 1.27 & Medium \\
\hline 1 & 5 & $\begin{array}{c}\text { I'm doing good actions in } \\
\text { sudden positions }\end{array}$ & 3.55 & 1.23 & Medium \\
\hline 3 & 4 & $\begin{array}{c}\text { I'm observing to understand } \\
\text { the instructions to ensure the } \\
\text { safety of implementation }\end{array}$ & 3.40 & 1.23 & Medium \\
\hline 5 & 9 & $\begin{array}{c}\text { I'm dealing with co-workers } \\
\text { in a civilized method }\end{array}$ & 3.29 & 1.11 & Medium \\
\hline 6 & 1 & $\begin{array}{c}\text { I'm dwelling on the job and } \\
\text { away from the distractions }\end{array}$ & 3.24 & 1.37 & Medium \\
\hline 7 & 6 & $\begin{array}{c}\text { I'm responding to directions } \\
\text { quickly }\end{array}$ & 3.22 & 1.29 & Medium \\
\hline 8 & 8 & $\begin{array}{c}\text { I'm maintaining good } \\
\text { appearance and elegance }\end{array}$ & 3.18 & 1.11 & Medium \\
\hline 9 & 7 & $\begin{array}{c}\text { I'm accomplishing the } \\
\text { paperwork quickly }\end{array}$ & 3.13 & 1.25 & Medium \\
\hline 10 & 10 & $\begin{array}{c}\text { I'm wense of } \\
\text { level of daily achievility and }\end{array}$ & 3.12 & 1.24 & Medium \\
\hline \multicolumn{2}{|c|}{ Dimension (official performance) as a whole } & 3.27 & 0.89 & Medium \\
\hline
\end{tabular}

Table 10 shows that the arithmetic mean for individual sample answers about dimension paragraph of official performance ranged between 
3.06 and 3.55. Paragraph 2 came first (I'm accomplishing my responsibility and duties correctly) with an arithmetic mean of 3.06 and medium-evaluation degree. While paragraph 10 came last (I feel satisfied with my level of daily achievement) with an arithmetic mean of 3.0 and with medium-evaluation degree. The arithmetic mean for dimension as a whole reached 3.27 with medium-evaluation degree.

Table 11. The arithmetic mean and standard variation for individual sample answers about paragraph dimension of additional official in a descending order

\begin{tabular}{|c|c|c|c|c|c|}
\hline Rank & Number & Paragraph & $\begin{array}{c}\text { Arithmetic } \\
\text { Mean }\end{array}$ & $\begin{array}{c}\text { Standard } \\
\text { Deviation }\end{array}$ & $\begin{array}{c}\text { Evaluation } \\
\text { Degree }\end{array}$ \\
\hline 1 & 2 & $\begin{array}{c}\text { The employees engaging in } \\
\text { work that isn't required of him }\end{array}$ & 3.80 & 0.97 & High \\
\hline 1 & 10 & $\begin{array}{c}\text { I'm leading the citizens and } \\
\text { providing help }\end{array}$ & 3.80 & 0.97 & High \\
\hline 3 & 3 & $\begin{array}{c}\text { I'm restricting in safety } \\
\text { instructions }\end{array}$ & 3.68 & 1.09 & High \\
\hline 4 & 1 & $\begin{array}{c}\text { I'm dealing with co-workers in } \\
\text { a civilized manner }\end{array}$ & 3.40 & 1.13 & Medium \\
\hline 4 & 9 & $\begin{array}{c}\text { I'm providing the service to } \\
\text { beneficiaries in a good way }\end{array}$ & 3.40 & 1.13 & Medium \\
\hline 6 & 4 & $\begin{array}{c}\text { I'm doing my utmost effort to } \\
\text { perform tasks in the fastest } \\
\text { time }\end{array}$ & 3.37 & 1.09 & Medium \\
\hline 7 & 8 & $\begin{array}{c}\text { I'm maintaining the secrecy of } \\
\text { transactions }\end{array}$ & 3.14 & 1.30 & Medium \\
\hline 8 & 7 & I'm treating offenders well & 2.95 & 1.23 & Medium \\
\hline 9 & 6 & $\begin{array}{c}\text { I'm maintaining equipment and } \\
\text { supplies }\end{array}$ & 2.77 & 1.19 & Medium \\
\hline 10 & 5 & I'm snapping the personal \\
knowledge & 2.74 & 1.29 & Medium \\
\hline \multicolumn{2}{|r|}{ Dimension (additional performance) as a whole } & 3.23 & 0.86 & Medium \\
\hline
\end{tabular}

Table 11 shows that the arithmetic mean for individual sample answers about paragraph dimension of additional performance ranged between 2.47 and 3.80. Paragraph 2 came first (the employee engaging in work that isn't required of him) with arithmetic mean between 2.074 and 3.80 and high-evaluation degree. While paragraph 10 came last (I'm snapping the personal knowledge) with an arithmetic mean of 2.74 and medium evaluation degree. The arithmetic mean for dimension as a whole reached 3.23 with medium-evaluation degree.

\section{Hypotheses Test Measure}

To check the impact of every dimension for work ethics of human resource management dimension on improving the performance of employees. Multiple Linear Regression was used for the analysis, to recognize if there was a statistically significant impact independent variables at the level of statistical significance of $a \leq 0.05$. This requires a check of appropriate data for hypotheses to Multiple Linear Regression analysis. This 
occurs by measuring some tests prior (and normality test to each dependent variable, independent variable, and moderating variable), and test of moral, explicative strength to model of Multiple Linear Regression analysis before applying it to test the sub-hypotheses for the study. This is shown below:

1- The check for the normality of dependent variables, independent variable, and moderating variables was done through using one-sample Kolomgorov-Smirnov test. Table 12 illustrates this.

Table 12. One-sample Kolomgorov-Smirnov test for dimensions of independent variable and dependent variable

\begin{tabular}{|c|c|c|}
\hline Dimension & $\begin{array}{c}\text { One-sample } \\
\text { Kolomgorov- } \\
\text { smirnov test } \\
\text { value }\end{array}$ & Statistical significance \\
\hline Polarize the human resource & 1.22 & 0.09 \\
\hline Training and development & 1.30 & 0.07 \\
\hline Rumination and rewarding of employees & 1.04 & 0.31 \\
\hline Evaluation of employees & 1.17 & 0.10 \\
\hline $\begin{array}{c}\text { Effectiveness of work ethics in human } \\
\text { resource management as a whole }\end{array}$ & 1.27 & 0.08 \\
\hline Official performance & 1.28 & 0.17 \\
\hline Additional performance & 1.16 & 0.15 \\
\hline Performance as a whole & 1.10 & 0.09 \\
\hline
\end{tabular}

It can be seen from table 12 that all statistically significant values for one-sample kolomgorov-smirnov test of independent variables and dependent variable shows that there was no statistical significance $(0.05 \geq a)$. This indicates that the independent variables and dependent variables follow the normal distribution. Also, they are based on the theory of central tendency, which states that if the sample size is bigger than 30 and has an arithmetic mean of $\mu$ and a variation of $\partial^{2}$, then the sampling distribution for arithmetic mean trenches from normal distribution.

2- Test the normal and explanatory strength of the model of Multiple Linear

Regression analysis was used. This was done through the following:

Linear correlation test: This has been used for the Linear correlation test in order to make sure that there is no high correlation between the independent variables that is based on the inflation coefficient of variation (VIF) and the variation allowable test (Tolerance) for each variable of independent variable. There should be independent variables of model that are independent of each other. This is to establish the purpose of the test by understanding that it is necessary for VIF not to exceed 10. Also, that the value of Tolerance should be from 0.05 and should account for the previous transactions for each independent variables. The results obtained are listed in table 13 as follows. 
Table 13. Inflation Coefficient of Variation Test and Tolerance for Independent Variables

\begin{tabular}{|c|c|c|}
\hline Field & Tolerance & VIF \\
\hline Polarize the human resource & 0.23 & 4.30 \\
\hline Training and development & 0.24 & 4.04 \\
\hline Ruminations and rewards & 0.45 & 2.22 \\
\hline Evaluation of employees & 0.42 & 2.40 \\
\hline
\end{tabular}

As it is shown in Table 13, the test inflation coefficient of variation values for all independent variables less than 10 ranged between 2.22 and 4.30. While the Tolerance value for all independent variables more than 0.05 ranged between 0.23 and 0.45 . Therefore, it can be said there is no high correlation problem between independent variables. This enhances the possibility of use in the model, after the inclusion of the independent variables in Multiple Linear Regression analysis, which is used to find out which of the independent variables have a statistically significant impact on the development variables, as well as to know the percentage of that impact, if any.

\section{Main Hypothesis}

There is no statistically significant impact at the level $a \leq 0.05$ for work ethics human resource exercise to improve the level of performance of employees in Greater Irbid Municipality. To validate this hypothesis, Multiple Linear Regression has been applied to the equation to study the impact of work ethics practices in human resource management in improving the level of performance of employees. Table 14 illustrates this.

Table 14. Results of application of Multiple Linear Regression to equation for studying the impact of work ethics in human resource management on improving the performance of employees

\begin{tabular}{|c|c|c|c|c|c|c|c|}
\hline Dimension & $\beta$ & $\mathrm{T}$ & $\begin{array}{l}\text { The statistical } \\
\text { significance }\end{array}$ & $\mathrm{R}$ & $\mathrm{R}^{2}$ & $\mathrm{~F}$ & $\begin{array}{r}\text { Statistical } \\
\text { significant }\end{array}$ \\
\hline $\begin{array}{l}\text { Polarize the } \\
\text { human } \\
\text { resource }\end{array}$ & 0.01 & 0.19 & 0.85 & \multirow{4}{*}{0.75} & \multirow{4}{*}{0.56} & \multirow{4}{*}{110.77} & \multirow{4}{*}{0.00} \\
\hline $\begin{array}{l}\text { Training and } \\
\text { development }\end{array}$ & 0.62 & 8.57 & 0.00 & & & & \\
\hline $\begin{array}{l}\text { Rumination } \\
\text { and rewards }\end{array}$ & 0.13 & 2.42 & 0.02 & & & & \\
\hline $\begin{array}{l}\text { Evaluation of } \\
\text { employees }\end{array}$ & 0.05 & 0.81 & 0.42 & & & & \\
\hline
\end{tabular}

Table 14 shows the following:

1- There is no statistically significant impact at the level of significance of $\mathrm{a} \leq 0.05$ to the dimensions of work ethics practices in human resource management in improving the performance of employees. The value of the overall correlation coefficient $(\mathrm{R})$ reached 0.75 . This is the value of statistical significance and it indicates to the degree of function 
correlation statistically between independent variables and dependent variables. The value $\mathrm{R}$-square reached 0.56 that is statistically significant. This explains the effectiveness of work ethics of human resource management in influencing the performance level, and this shows the effectiveness of the work ethics of human resource management. This explains what percentage of $65 \%$ form the change in employees' performance level and the test value (f) reached 110.77 with a statistical significance of 0.00 . A statistical significance level of $a \leq 0.05$ confirms the presence of variation in the ability of the independent variables to influence the department variable.

2- There is a statistically significant impact at the level of significance of $\mathrm{a} \leq 0.05$ for dimensions of training, development, and pay and bonuses of employees on the level of performance of employees. Here, $\mathrm{B}$ and $\mathrm{T}$ were positive values that were statistically significant.

3- There is no statistically significant impact at the level of $a \leq 0.05$ for dimensions of polarizing human resource and education employees on the level of performance of employees. Here, $\mathrm{B}$ and $\mathrm{T}$ were positive values that were statistically significant.

Based on the above, the main hypothesis in static formula is accepted and the zero formula (plot 1) and scatter plot of the relationship between work ethics practices in human resource management and the level of performance of employees is rejected.

Figure 1. Scatter plot of the relationship between work ethics practices in human resource management and the level of performance of employees

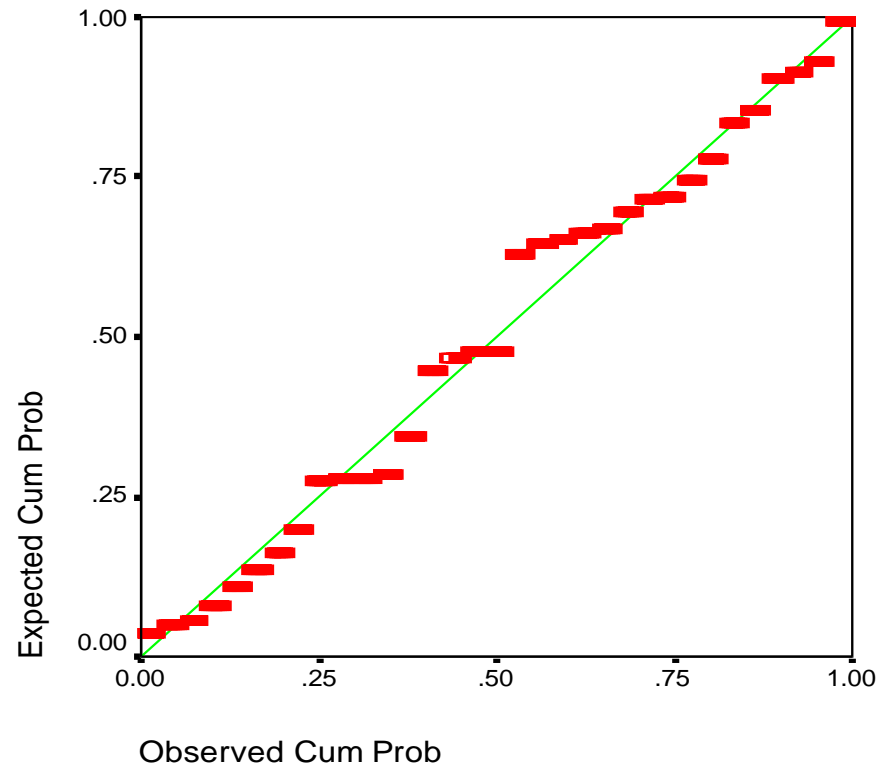


Fig. 1 shows that the degree of the relationship between work ethics practices in human resource management and the level of performance of employees was strong. However, it was not quite strong where there was a proliferation of points in the scatter plot around the straight line.

\section{The First Sub-hypothesis}

There is no statistically significant impact at the level of significant of $\mathrm{a} \leq 0.05$ on the dimension of work ethics practices in human resource management in improving the performance of employees in Greater Irbid Municipality. To validate this hypothesis, Multiple Linear Regression has been applied to study the impact of work ethics practices in human resource management on improving the performance of employees. Table 15 illustrate this.

Table 15. Results of application of Multiple Linear Regression equation for the studying of the impact of work ethics in human resource management on improving the performance of employees

\begin{tabular}{|c|c|c|c|c|c|c|c|}
\hline Dimension & $\beta$ & $\mathrm{T}$ & $\begin{array}{c}\text { The Statistical } \\
\text { significance }\end{array}$ & $\mathrm{R}$ & $\mathrm{R}^{2}$ & F & $\begin{array}{c}\text { Statistical } \\
\text { significant }\end{array}$ \\
\hline $\begin{array}{l}\text { Polarize human } \\
\text { resource }\end{array}$ & 0.01 & 0.15 & 0.88 & \multirow{4}{*}{0.77} & \multirow{4}{*}{0.58} & \multirow{4}{*}{122.46} & \multirow{4}{*}{0.00} \\
\hline $\begin{array}{l}\text { Training and } \\
\text { development }\end{array}$ & 0.52 & 7.36 & 0.00 & & & & \\
\hline $\begin{array}{l}\text { Rumination and } \\
\text { rewards }\end{array}$ & 0.16 & 3.11 & 0.00 & & & & \\
\hline $\begin{array}{c}\text { Evaluation of } \\
\text { employees }\end{array}$ & 0.19 & 3.53 & 0.00 & & & & \\
\hline
\end{tabular}

Table 15 shows the following:

1- There is no statistically significant impact at the level of significance of $\mathrm{a} \leq 0.05$ on the dimensions of work ethics practices in human resource management in improving the official performance of employees. The value of the overall correlation coefficient $(\mathrm{R})$ reached 0.77 , which is statistically significant. This indicates the degree of function correlation of statistical significance between independent variables and dependent variable. The value of R-square reached 0.58 , which is statistically significant. This explains the effectiveness of the work ethics of human resource management in influencing the performance level. Furthermore, it shows the effectiveness of the work ethics of human resource management. This is shown by the employee performance level value of $58 \%$. The test value (f) reached 122.46 at a statistically significant level of $a \leq 0.05$. This confirms the presence of variation in the ability of the independent variables to influence the department variable.

2- There is a statistically significant impact at the level of significance of $a \leq 0.05$ for the dimensions of training and development and pay and 
bonuses of employees on the level of official performance of employees. Here, $\mathrm{B}$ and $\mathrm{T}$ were positive values with statistical significance.

3- There is no statistically significant impact at the level of significance of $\mathrm{a} \leq 0.05$ for the dimensions of polarizing human resource and education of employees on the level of official performance of employees. Here, B and $T$ were positive values with statistical significance.

Based on the above, the main hypothesis in static formula is accepted and the zero formula is rejected.

\section{The Second Sub-hypothesis}

There is no statistically significant impact at the level of significance of $a \leq 0.05$ on the dimension of work ethics practices in human resource management in improving the performance of employees in Greater Irbid Municipality. To validate this hypothesis, the Multiple Linear Regression has been applied to study the impact of work ethics practices in human resource management on improving the level of performance of employees. Table 15 illustrate this.

Table 16. Results of application of Multiple Linear Regression equation on the study of the impact of work ethics practices in human resource management on improving the performance of employees

\begin{tabular}{|c|c|c|c|c|c|c|c|}
\hline Dimension & $\beta$ & $\mathrm{T}$ & $\begin{array}{l}\text { The statistical } \\
\text { significance }\end{array}$ & $\mathrm{R}$ & $\mathrm{R}^{2}$ & $\mathrm{~F}$ & $\begin{array}{c}\text { Statistical } \\
\text { significant }\end{array}$ \\
\hline $\begin{array}{l}\text { Polarize human } \\
\text { resource }\end{array}$ & 0.03 & 0.37 & 0.17 & \multirow{4}{*}{0.65} & \multirow{4}{*}{0.41} & \multirow{4}{*}{62.20} & \multirow{4}{*}{0.00} \\
\hline $\begin{array}{l}\text { Training and } \\
\text { development }\end{array}$ & 0.61 & 70.36 & 0.00 & & & & \\
\hline $\begin{array}{l}\text { Rumination } \\
\text { and rewards }\end{array}$ & 0.09 & 1.40 & 0.16 & & & & \\
\hline $\begin{array}{c}\text { Evaluation of } \\
\text { employees }\end{array}$ & 0.07 & 0.15 & 0.25 & & & & \\
\hline
\end{tabular}

Table 16 shows the following:

1- There is no statistically significant impact at the level of significance of $\mathrm{a} \leq 0.05$ on the dimensions of work ethics practices in human resource management in improving of the additional performance of employees. The value of the overall correlation coefficient $(\mathrm{R})$ reached 0.65 , which is statistically significant and indicates the degree of function correlation between independent variables and dependent variable. The value of Rsquare reached 0.41 , which is statistically significant and shows the effectiveness of the work ethics of human resource management in influencing the performance level. This shows the effectiveness of work ethics of human resource management and explains the value of $41 \%$ for employees' performance level. The test value (f) reached 62.20 at a statistically significant level of $a \leq 0.05$. This confirms the presence of 
variation in the ability of the independent variables to influence the department variable.

2- There is a statistically significant impact at the level of significance of $\mathrm{a} \leq 0.05$ for the dimensions of training and development on the level of additional performance of employees. Here, $\mathrm{B}$ and $\mathrm{T}$ were positive values with statistical significance.

3- There is no statistically significant impact at the level of significance of $\mathrm{a} \leq 0.05$ for dimensions of polarizing human resource, rumination and rewards employees, and evaluation employees on the level of additional performance of employees. Here, $\mathrm{B}$ and $\mathrm{T}$ were positive values with statistical significance.

Based on the above, the main hypothesis in static formula was accepted and the zero formula was rejected.

\section{Conclusion: Findings and Recommendations Search Results}

Through data analysis and hypothesis testing, the study arrived at following set of results:

1- The study proved that the arithmetic mean and standard deviation from the answers of the respondents about the dimensions of work ethics in human resource management was evaluated based on median degrees. They were arranged in descending order as follows: training and development, wages and rewards of employees, polarizing human resources, and evaluating employees.

2- The study proved that the arithmetic mean and standard deviation from the answers of the respondents about the dimensions of work ethics of human resource management was evaluated based on median degrees. They are arranged in descending order as follows: official performance and additional performance.

3- As the study proved, the evaluation of the respondents to polarize human resources management as a whole was medium. The exception was the paragraph ensuring equal opportunity for applicants for positions in the municipality and the paragraph of measure of polarize fairness. The instrument and patronage rating evaluation was low.

4- As the study showed, the evaluation of the respondents for dimensions of training and development as a whole was medium. The paragraph of training and development came first, as a right of employees to enhance the efficiency of the organization. While the training paragraph that focuses on social and ethics in accordance with the organization's culture came last.

5- As the study showed, the evaluation of the respondents for dimensions of wages and rewards of employees as a whole was medium. This came 
first: the paragraph focusing on the package of indirect compensation such as health insurance and social security. While the paragraph that takes into account the efficiency in determining wages and lowevaluation degree came last.

6- The study also showed that the evaluation of the respondents to dimensions of employees' evaluation as a whole was median. The paragraph on the evaluation process focuses on recent performances and neglecting performances during the year came first. While rewards for organization achievers who offer new ideas came last.

7- The study proved that the evaluation of respondents for the dimension of official performances as a whole was medium. The paragraph "to fulfill my duties and my responsibilities with accuracy" came first. While, the paragraph "I was satisfied with the level of daily achievement" came last.

8- The study also proved that the evaluation of respondents for the dimension of ideational performance as a whole was medium. The paragraph: the employees sharing in the business is unrequired came first. While the paragraph: apply personal knowledge came last.

9- The practices of human resource management of ethical aspects which are based on the principles of justice, equality, transparency, and integrity in their activities have a dramatic impact on morals, which in turn is reflected on the level of performance of employees.

10-The main hypothesis was developed to measure the impact of work ethics practices in human resources management in improving the level of performance of employees in Greater Irbid Municipality in Jordan. The result confirmed this hypothesis. These results have been reached through the analysis of sub-hypothesis.

\section{Recommendations}

1- The researcher recommends the need for adherence to work ethics in all the activities and functions of the organization for its positive reflections on the performance of employees.

2- Institutions must ensure equal opportunities to applicants for jobs and the procedures of polarization are fair and far from instrumentality and patronage.

3- The researcher recommends the need to focus on training and development programs on social and ethical aspects in accordance with organization's culture.

4- The researcher recommends that the institution should take into account the achievers who are providing new ideas in determining wages and remuneration.

5- Further studies about the obstacles that prevent institutions' commitment to social responsibility and work ethics. 


\section{References:}

Abbas, Suhailamohammad (2006). Human resource management, house Wael for publication, Amman, second edition.

Moussawi, Sinan (2004). Human resource and effect of globalization on them, Magdalawi house for population and distribution, Amman, the first edition

Al-Munjed in language and media, almushraq house, Beirut, the fortieth edition

AL FayrozAbaddi, Mohammad Yacoub (2003). Almuheet dictionary, revive the Arab heritage house, Beirut, the fifth edition.

Al- Al-Doori, Zakaria and Others (2010). The principles and entrances the administration and their functions in the twenty-first century, Yazouri house for publication, Amman.

Dorah , Abd-Abari Ibrahim (2003). Human performance technology in organization ,theoretical principles and its implications in the contemporary environment, the Arab Organization for administrative development , Amman.

Zidan, Mahmoud Mustafa (1984). Supervision and production, Okath for publication and distribution, Riyadh.

Abu Baker, Mustafa Mohammad (2010). Values and ethics work, university house, Alexandria, the first edition.

AL-Galibi, TaherMohsain and Alamiri, Salih Mahdi (2010). Social responsibility and business ethics, "business and society", Wael house for publication, Amman the third edition.

Yaghi, Mohammad Abed Al Fatah (2001). Ethics in administration, Al Yakdah for publication and distribution, Amman.

Al-Sakarneh, Bilal Khalaf (2009). Business ethics, Almaserah house, Amman, first edition.

Jeldeh, SleemBotros (2010). The ethics of administration in the business world the media house, Amman, the first edition.

Aladela, Nasser Mohammad (1995). The human and organizational behavior, total comparative perspective, the institute of public administration, Riyadh.

Atyani,Murad Saleem and Abu Salma, Abdullah Jamil (2014). The impact of practice work ethics HR departments to achieve the satisfaction of employees, field study in cellular communication companies in Jordan, science administrative studies magazine, Vol. 41, the second number

Mayer, David, Kuenzi, Greenbaum, Rebecca (2011). "Examining the link between ethical leadership and employee misconduct: The mediating role of ethical climate" Journal of business ethics. Issue95. Pages 716.USA.

Almqss, Mohammad, and Kheirshah , saad and Almesaied, Mufdi and Tashma, Ghazi (2011). Provides public function ethics in functional 
performance in the breeding Badia middle manager , the magazine of culture and development , Al-Isra'a university, Jordan.

Hussein, Laithsaad Allah, and Jamil, ReemSaad (2009). Social responsibility toward employees and their reflection on the work 'a study of the opinions sample of employees of some hospitals in the city of AL-Mousel" research presented to the scientific third conference for faculty of economic and administrative, Applied Science University.

John Simmons (2008). Ethics and morality in human resource management, Social Responsibility Journal, Issue 4 (1/2):PP 8 -23.

Al hanith Khaled Abdullah (2003). Organizational values and their relationship to the efficient performance , applied study , on medical services workers at the Ministry of Defense and Aviation in Riyadh , master unpublished Naif Arab university for security sciences in Riyadh. 